\title{
Distinctive Attitude of Datuk Maringgih in Marah Rusli's Novel Siti Nurbaya
}

\author{
Rahmi Rizkya, M. Manugeren, and Susi Ekalestari \\ Universitas Islam Sumatera Utara (UISU), Medan, Indonesia
}

\section{Abstract}

This research deals with the distinctive attitude of Datuk Maringgih in Marah Rusli's novel Siti Nurbaya. Datuk Maringgih is described as a person who is old, strong, rebellious and has a lot of money and always has a strategy in everything. The attitude shown by this person is also related to society. The research is conducted means of descriptive qualitative method. Qualitative research is a research method that focuses on understanding social phenomena that occur in society. Descriptive qualitative is usually designed to examine morality and other problems in society. The researcher uses attitude theory where attitude is a mental and neural state of readiness, organized through experience, exerting a directive or dynamic influence on the individual's

Corresponding Author:

Rahmi Rizkya

rahmirizkyaanandania@ gmail.com

Received: 1 July 2019

Accepted: 18 July 2019

Published: 31 July 2019

Publishing services provided by Knowledge E

(c) Rahmi Rizkya et al. This article is distributed under the terms of the Creative Commons Attribution License, which permits unrestricted use and redistribution provided that the original author and source are credited

Selection and Peer-review unde the responsibility of the AICLL 2019 Conference Committee.

\section{G OPEN ACCESS} response to all objects and situations with which it is related. The source of data is from the novel. The data in this research is the entire texts in the book. The technique used to analyze data is heuristic and hermeneutic. The research result shows that Datuk Maringgih had three distinctive attitudes: Defending land from the invaders, helping others and consistence.

Keywords: Consistency, land defense, attitude.

\section{Introduction}

Siti Nurbaya a well-known novel written by Marah Rusli is the landmark of Balai Pustaka Era in Indonesia. This novel has become a topic of academic discussion not only in Indonesia but also in some other countries and even has been translated into Russian language. By this a praise and appreciation should be given to this novel as this novel has been accepted in the international world of literature

Siti Nurbaya was published in 1922 and this year is known as Balai Pustaka Period. The writer Marah Rusli besides beings a veterinarian is claimed to be an in-born talented writer and nicknamed The Father of Modern Indonesian Roman by H.B Jasin. Many of the best known writers are at one time or another members of the editorial staff of Balai Pustaka. It is this firm which provides an outlet and incentive to native writers to such extent that is role in modern Indonesian literature can scarcely be overestimated. 
The appearance of Marah Rusli's novel Siti Nurbaya in 1922 is an important landmark in the history of Indonesian literature. The novels of Rusli make a complete break with the older traditional literature by depicting real-life situations and characters rather than indulging in fantansy.

The author, Marah Rusli, was born in Padang, on August, 1889, the only child of a civil service district head in West Sumatra. His father's title, Sultan Pangeran, indicated descent from the old Pagaruyung monarchy. His mother also claimed aristocratic lineage, but from Java. Cross-ethnic marriages in those days and for many decades to come are discouraged because difficulties arising from differences in tradition of the various ethnic groups in the Indies. Marah Rusli was educated at a Dutch medium school in Padang and thereafter at the influential Raja's school in Bukit Tinggi. Upon graduation in 1910, he entered the Veterinary School and commenced his long-life career in government veterinary service. In 1991, he married a title girl from Bogor, West Java, Nyai Raden Ratna Kecana Wati. Although this marriage was against his parents; wishes, it proved to be a happy and lasting one having three children.

Siti Nurbaya is a story that happens in Padang, West Sumatera. The story tells about two teenagers whose name Siti Nurbaya and Samsul Bahri. They are neighborhood; they are used to playing together since they are since child. Then, when they grow up become young beautiful lady and young handsome man, they fall in love each other. In the other side, Datuk Maringgih is described as a person who is old, strong, rebellious and always has a strategy in everything, who has come up from the lowest class and managed to reach an influential position through his many business holding. $\mathrm{He}$ is painted a thoroughly bad character and becomes rich, so rich that he cannot tolerate that there should be anyone wealthier than he is the native society of Padang. $\mathrm{He}$ becomes the creditor of Sutan Mahmud, the penghulu of the noble descent and holder of a high civil post, and father of Siti Nurbaya, a lover of Samsul Bahri. Datuk Maringgih ruins Siti Nurbaya's father,a rival merchant and takes the daughter as payment of the debt.

\section{Literature Review}

Attitude is the concrete form of desire. Therefore, this attitude is often regarded as a desired or undesirable vote statement. As stated by Robbinson (in Mustakim, et.al., 2015) attitude is the statement of votes, whether it is needed or not, toward object, person or event. According to Allport (in Mustakim, et. al., (2015), attitude is a mental and emotional readiness, organized through experience, support or influence the dynamics 
of individual responses to all objects and situations that are associated with it. While Greenberg and Baron (in Mustakim, et. al., 2015) defines attitude as a group of feelings, beliefs and behaviors that are relatively stable to the object, human beings and certain institutions.

Several attitudes within the broad definition readiness of the psyche to act or react in a certain way. Attitudes very often come in pairs, one conscious and the other unconscious. Attitudes are held with respect to some aspect of the individual's world, such as another person, a physical object, a behavior, or a policy. Therefore, the way a person reacts to his surroundings is called his attitude. Attitudes as relatively lasting clusters of feelings, beliefs, and behavior tendencies directed towards specific persons, ideas, objects or groups.

Attitude as a mental or neural state of readiness, organized through experience, exerting a directive or dynamic influence on the individual's response to all objects and situations to which it is related. A simpler definition of attitude is a mindset or a tendency to act in a particular way due to both an individual's experience and temperament.

\section{Research Method}

This research was library research that used qualitative method to analyze the data from the novel entitled Siti Nurbaya by Marah Rusli. The object of the study is distinctive attitude aspects of Datuk Maringgih. The next steps taken were collecting, identifying and understanding fully the concepts and meanings as well as the distinctive attitude aspects. Various sources out of the novel are also taken to better analysis. The qualitative data are considered to be the rough materials researchers collect from the world they are studying; they are the particulars that from the basis of analysis.

The source of the data in this research consists of two types. They are primary data and secondary data. As stated by Khotari (2004) the primary data are those which collected afresh and for the first time, and thus happen to be original in character. The secondary data, on the other hand, are those which have already been collected by someone else and which have already been passed through the statistical process.

In this research, the primary data is the novel Siti Nurbaya written by Marah Rusli. The secondary data is documents, script and other relevant sources that are related to the topic. The data collection procedures divided into some steps. The first step is the researcher observed the novel. Then, the researcher read the novel. Next, the researcher was searching information that is related to the novel and the topic of this study also. As stated by Khotari (2004) content-analysis consists of analysis the contents 
of documentary materials such as books, magazines, newspapers and the contents of all other verbal materials which can be either spoken or printed.

\section{Result and Discussion}

The author tries to analyze the aspects of Distinctive attitude in Marah Rusli's Novel Siti Nurbaya. The distinctive attitude consists helping others, consistence and defending land from the invaders.

\subsection{Helping others}

Sutan Mahmud's wish to lend the money three thousand rupiah to Datuk Maringgih to finance the marriage of his niece, Rubiah to the man of her choice. In adat of Padang, marrying and financing the marriage of a niece becomes an obligation of mamanda or uncle, not the obligation of the parents.

The following is a quote from a conversation between Sutan Mahmud Datuk Maringgih

"It has been half-two" Maringgih stated. After seeing his a big watch with golden rope that was taken from his pocket. "So, may I borrow three thousand rupiah?", Sutan Mahmud asked."Of course" Maringgih replied. (Rusli 2002: 16)

Based on the quote above, Datuk Maringgih is willing to lend the money to Sutan Mahmud. Sutan Mahmud needed three thousand rupiah so he asked Datuk Maringgih to give him a loan. It can be concluded that he was a kind person because he gave a loan to Sutan Mahmud. Sutan Mahmud is happy.

\subsection{Consistency}

This merchant is a person who is very stingy and greedy, has no affection and is ruthlessly rude. As long as he will get money, as long as he wants it, he doesn't care about anything, he doesn't fear anything. He is very consistent in keeping his money from being wasted. (Rusli 2002:84)

Based on the above quotation, Datuk Maringgih is depicted as a very stingy man even though he is known as a rich man. He is difficult to spend his money to the something that is urgent and important. He also thinks several times when he wanted to spend 
his money. He always said to his heart "I give this money or not?". He pretends like a rich man even though he has not the money. Being consistent as a very thrift man. His attitude was too thrifty and stingy cause Datuk Maringgih is disliked by the other character and influences the emotion of other characters in the novel. Other characters are very hate Datuk Maringgih as their response that is depicted in the novel.

\subsection{Defending land from invaders}

"The reason that we invited brothers and sisters tonight that I wanted to announce about the new rules that the invaders has decided about the payment of the taxes. Apparently, the Dutch have not been satisfied to suck our blood, energy and sweat. Therefore, let's defend this ninik mamak land so that we were free from taxes imposed by the invaders. If this continues, we must prepare ourselves to war against the invaders so we are free of tax or belasting payments". (Rusli 2002:250)

The reason that we invited brothers and sisters tonight that I wanted to announce about the new rules that the invaders has decided about the payment of the taxes. Apparently, the Dutch have not been satisfied to suck our blood, energy and sweat. Therefore, let's defend this ninik mamak land so that we were free from taxes imposed by the invaders.

Based on the above quotation, Datuk Maringgih tells about the condition occurs in his hometown. When the invaders wanted to enter the hometown, they include Datuk Maringgih, have to pay the taxes to the invaders. In addition, the invaders has suck their blood, energy and sweat. In other words, the invaders had racked up sweat, seized the produce and the colonizers would also set taxes on the land of Padang as a birthplace and ground for indigenous people. Defending land against the invaders, Datuk Maringgih invites his brother and sister to defend their ninik mamak land against the invaders. He hopes defending land from invaders make him and his brothers and sisters are spared to pay taxes to the invaders.

\section{Conclusion}

Datuk Maringgih in Siti Nurbaya's novel is describes as a person who is old, strong, rebellious and always has a strategy in everything, who is risen from the lowest class and manage to reach an influential position through many of his businesses. Datuk Maringgih, who has been described above, is one of the characters who develop from 
an antagonist to become a protagonist because of his distinctive attitude, including helping others by lending money, defending land from the invaders, etc. Behind his hard attitude, Datuk Maringgih is a loyal person to his country and do not betray his country and save his country from the belasting regulations set by the invaders. He also became a leader in warfare against invaders even though he was shot dead during the war.

\section{References}

[1] Asri, Muhammad. Mohd Tahir, Lokman. (2015). The Effect of Personality Value of Principals toward Attitude, Discipline, Qualities and Communications of Work. Journal of Education and Learning.Vol.9, No. 01 p.61-70. Retrieved on 15 April 2019 from http://journal.uad.ac.id/index.php/EduLearn/article/view/1006/pdf_77

[2] Febrina, Diaz. (2018). Feminism in Pramoedya Ananta Toer's Novel Gadis Pantai. In the $1^{\text {st }}$ Annual International Conference on Language and Literature, KnE Social Sciences \& Humanities. P.247-254. Retrieved on 15 April 2019 from https: //knepublishing.com/index.php/Kne-Social/article/view/1936/4328

[3] Jain, Vishal. (2014). 3D Model of Attitude, International Journal of Advanced Research in Management and Social Sciences, Vol. 3, No. 3, P. 145-154 Retrieved on 16 April 2019 from http://garph.co.uk/IJARMSS/Mar2014/1.pdf

[4] Khotari,C.R. (2004). Research Methodology: Methods and Techniques. New Delhi: New Age International (P) Ltd., Publishers.

[5] Mustakim, Salina. Mustapa, Ramlee. Lebar, Othman. (2015). Critical Analysis of the supportive and Suppressive factory for the Children's Literature Program in Malaysia, Journal of Education and Learning vol 9 no 01. Retrived on 19 April 2019 from https://books.google.co.id/books?id=FzOHCgAAQBAJ\&pg=PA63\&lpg= PA63\&dq $=$

[6] Pickens, Jeffrey. (2005). Attitude and perceptions, Journal of Psychology. Vol 2, No. 12. P.51-63 Retrieved on 17 April 2019 fromhttps://www.researchgate.net/publication/ 267362543_Attitudes_and_Perceptions

[7] Rusli, Marah. (2002), Sitti Nurbaya, Jakarta: Balai Pustaka. 